\title{
A new species of pygmy mole cricket (Orthoptera: Tridactylidae) from the Lake Wales ridge of Florida and new records of Ellipes eisneri from the northern Brooksville ridge
}

\author{
BRANDON WOO'
}

1 Cornell University, Comstock Hall, Department of Entomology, Ithaca, NY 14853, USA.

Corresponding author: Brandon Woo (bmw95@cornell.edu)

Academic editor: Hugh Rowell | Received 18 March 2021 | Accepted 30 April 2021 | Published 27 September 2021

http://zoobank.org/91A6E44D-F43E-45A1-9E57-D2854959D32B

Citation: Woo B (2021) A new species of pygmy mole cricket (Orthoptera: Tridactylidae) from the Lake Wales Ridge of Florida and new records of Ellipes eisneri from the northern Brooksville Ridge. Journal of Orthoptera Research 30(2): 131-143. https://doi.org/10.3897/jor.30.65603

\begin{abstract}
Pygmy mole crickets (Orthoptera: Tridactylidae) are usually associated with the edges of ponds and streams, but in the sandy uplands of Florida, at least two lineages of these insects have evolved to live in xeric scrub and sandhill habitats. Very little work has been done with scrub tridactylids since they are tiny and often difficult to collect. In this paper, the pygmy mole cricket Ellipes deyrupi sp. nov. is described from the northern Lake Wales Ridge of Florida. It is sympatric at all known locations with another scrub tridactylid, Neotridactylus archboldi Deyrup \& Eisner, but has not been found co-occurring with the closely related Ellipes eisneri Deyrup. The habits of this new species are convergent with both $N$. archboldi and E. eisneri. In addition, new records of Ellipes eisneri are presented, extending this species' known distribution to the Northern Brooksville Ridge. Both species of scrub Ellipes are found in restricted geographic ranges and suffer from a lack of study and recognition. Conservation implications for these two species are discussed.
\end{abstract}

\section{Keywords}

Distribution, Florida endemics, sandhill, scrub, taxonomy, Tridactylinae

\section{Introduction}

The pygmy mole crickets, or Tridactylidae (Orthoptera: Caelifera: Tridactyloidea), are a family of small, burrowing orthopterans with a worldwide distribution (Deyrup and Eisner 1996). There are currently seven species known in the Nearctic region, with five recorded in Florida (Günther 1975, 1977). Three of these, Neotridactylus apicialis (Say, 1825), Ellipes minuta (Scudder, 1862), and E. gurneyi Günther, 1977, are fully winged, widespread in the southern USA, and occur in wet, sandy areas along water, as is typical for most members of the family. The other two species, N. archboldi Deyrup \& Eisner, 1996, and E. eisneri Deyrup, 2005, are flightless and endemic to ridge systems of central Florida, where they occur in open patches of bare sand within scrub $(N$. archboldi) or sandhill (E. eisneri) habitats. They are able to occur in these xeric environments because of the presence of a subsurface layer of algae in the bare patches of sand they inhabit. This pro- vides them with a source of food that is transiently available when rains occur, at which time the insects come to the surface and construct feeding burrows (Deyrup and Eisner 1996). Their habitat and food restrictions, as well as their flightless nature, mean that populations of scrub tridactylids are often isolated from each other, both within and between different ridge systems.

The Florida scrub is a unique and threatened habitat restricted to a series of ridges and dunes formed from Miocene, Pliocene, or Pleistocene shorelines, during which time the rest of the state was underwater (Deyrup 1989). These ridges served as biotic refuges during glaciation events, and today serve as ecological islands, where isolated populations of many species have diverged into distinct species. Despite being located in a subtropical region with high precipitation, the scrub is a rather dry environment owing to the excessive draining of water through its fine-grained sands (Menges 1999). Because of these conditions, it supports a distinct community of organisms specially adapted to drought. Florida scrub is characterized by low evergreen oaks (Quercus spp.) and sand pine (Pinus clausa (Chapm. ex Engelm.)) Vasey ex Sarg.), often with the ericaceous shrub Ceratiola ericoides Michx., interspersed with patches of bare white sand where many endemic herbaceous plants and lichens occur (Menges 1999). Sandhill, or 'high pine,' is another xeric habitat that is found on the Florida sand ridges but which also extends into other southeastern states (Myers 1985). This environment has a canopy of longleaf pine (Pinus palustris Mill.) and turkey oak (Quercus laevis Walter) and is more densely herbaceous than scrub, with abundant Aristida spp. grasses dominating (Menges 1999). Both scrub and sandhill are fire-maintained ecosystems, with sandhill burning more frequently than scrub (Myers 1985).

The oldest and longest of Florida's sand ridges, and the one with the highest levels of endemism, is the Lake Wales Ridge (LWR), which extends in central Florida from just south of the Orlando area to just north of Lake Okeechobee (Deyrup 1990). The LWR contains a distinctive type of habitat, called yellow sand scrub, which is an intermediary between classic scrub and sandhill (Deyrup and Carrel 2012). This habitat occurs on higher elevated sites with yellow sand and large populations of scrub hickory 
(Carya floridana Sarg.) and can vary from dense to more open scrub. There appears to be several arthropod species restricted to yellow sand scrub, including the Highlands tiger beetle (Cicindelidia highlandensis Choate, 1984), a candidate for federal protection (Deyrup and Carrel 2012). The LWR is one of the best studied ridges since it is the home of the Archbold Biological Station (ABS), which has conducted research on LWR endemic organisms since 1941. A total of 91 species of arthropods are known to be restricted to scrub habitat on the LWR (Deyrup and Carrel 2012), including six described species of Orthopterans.

Most Florida scrub endemic arthropods are poorly known due to their small sizes, restricted geographic ranges, and habitat specializations (Deyrup 1990), which are often such that only targeted collecting will reveal individuals. The scrub tridactylids are particularly difficult to locate, since they are only reliably found at or near the surface of the sand within a few hours after a rain. Their presence can sometimes be predicted in periods of drier weather, however, by the presence of small, excavated mounds of sand (tumuli) created when the insects burrow vertically downward in patches of open sand. Even when populations are located, individuals are a challenge to capture due to their impressive leaping abilities. Deyrup and Carrel (2012) completed an extensive sampling effort of LWR endemic arthropods across 23 different protected scrub preserves. In the course of that work, specimens of an unusual tridactylid were collected on the east side of the north-central LWR that clearly represented an undescribed species. The species was recognized as new by Deyrup (pers. com.) but has remained undescribed until now.

\section{Methods}

Collection.-Initial specimens of the new species were collected in yellow bowl traps (always following rain) during a 2009 survey of arthropods endemic to the Lake Wales Ridge. Additional material was collected by the author in August 2018 at the Tiger Creek Preserve and in August 2019 at two roadside sites east of Lake Marion. These two localities, as well as roadside sites on the Brooksville Ridge that might harbor Ellipes eisneri populations, were located using Google Maps. The author made several trips to the Brooksville Ridge during June and July 2018 in search of E. eisneri, but dry conditions kept the insects deep underground and out of reach. On July 28 and 29, 2018, the weather was more favorable, and specimens of E. eisneri were collected at five sites. All tridactylid specimens were collected either by carefully digging up the raised burrows immediately after rain or by sifting dry sand around the tumuli.

Determination.-Specimens of E. eisneri were identified using Deyrup (2005). No other known tridactylid species has the abbreviated wings and pale color pattern of E. eisneri, except for the new species described below. The new species is a member of the genus Ellipes Scudder, 1902, due to the extreme reduction of the hind tarsus. Its pale white and brown coloration distinguishes it from all other species of the genus, except for E. albicollatus Günther, 1977 and E. eisneri. E. albicollatus is described as having the caudal margin of the pronotum all white, with a white spot in the middle of the anal field of the tegmen. This species differs in other aspects of its coloration as well as in the shape of the female subgenital plate and is also known only from Brazil. Range, as well as the characters given below, will separate E. eisneri and the new species.

Measurements and terminology--Measurements were made to the nearest $0.5 \mathrm{~mm}$ by hand using a ruler and dissecting microscope
(Wild Heerbrugg, Heerbrugg, Switzerland). Terminology follows Deyrup (2005).

Photographs and maps.-Live nymphs and adults of both species were photographed in situ using a Canon EOS Rebel T3 with an attached Canon $100 \mathrm{~mm}$ macro lens and an external flash (Sunpak Auto 383 Super connected with a CowboyStudio 4 Channel Wireless Hot Shoe Flash Trigger \& Receiver). Collected nymphs and adults were photographed in a whitebox studio setup using the same equipment, with the addition of Canon extension tubes (EF25 and EF12 II) to the camera. Images of the habitat and tumuli were taken with an iPhone. Images of preserved specimens were made using a Canon EOS 6D with attached MPE $65 \mathrm{~mm}$ macro lens (20X zoom lens used for the terminalia and stridulatory apparatus) and Macro Twin Lite MT-24EX flash on a Cognisys Stackshot $3 \mathrm{X}$ system. Images were stacked using Zerene Stacker v.1.04 (Zerene Systems LLC, Richland, WA). All images were processed using Adobe Lightroom CC 2015.8 to crop and adjust white balance. Composite figures were created using Adobe Photoshop CC, v.14.2.1. Maps were created with SimpleMappr (Shorthouse 2010). GPS data were acquired using Google Maps.

\section{Depositories.-}

ABS Archbold Biological Station Arthropod Collection, Venus, FL, USA;

ANSP Academy of Natural Sciences, Philadelphia, PA, USA;

CUIC Cornell University Insect Collection, Ithaca, NY, USA;

FSCA Florida State Collection of Arthropods, Gainesville, FL, USA;

UMMZ University of Michigan Museum of Zoology, Ann Arbor, MI, USA

\section{Results}

\section{Key to the species of Tridactylidae found in Florida (modi- fied from Günther 1975 and Günther 1977).}

Larger, body length 3.8-10 mm; hind tarsus present......Neotridactylus 2 Smaller, length 3-5 mm; hind tarsus reduced to a tiny flap concealed between the hind tibial spurs ............................................... Ellipes 3

2 Larger, length 5.5-10 mm; fully winged; swimming plates on hind tibia present; color variable; usually found in sandy or muddy areas along water.................................................................... apicialis

- $\quad$ Smaller, length 3.8-4.9 mm; tegmina abbreviated, hind wings absent; swimming plates absent; uniformly dark colored; always found in xeric scrub habitats....................................................... archboldi

3 Fully winged; color variable but never uniformly pale; usually found in sandy or muddy areas along water.................................................. 4 Tegmina abbreviated, hind wings absent; coloration pale white and brown; always found in xeric scrub or sandhill habitats.................. 5 Antennae in both sexes 10-segmented ............................... E. minuta Antennae in the male 11-segmented, in the female 12-segment-

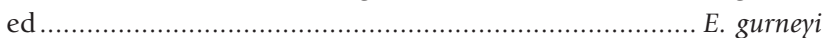
Smaller, length 3.3-3.5 mm; head blackish brown with narrow cream lines along inner orbits and coronal and frontal sutures; found in open sandhill habitat on the Brooksville Ridge..... E. eisneri Larger, length 3.5-4.1 mm; head white with irregular blackish brown band at its base and an irregular line of the same color between the compound eyes; found in yellow sand scrub habitat on the northern Lake Wales Ridge ……………………………....... E. deyrupi sp. nov. 


\section{Taxonomy}

Family Tridactylidae Brullé, 1835

Subfamily Tridactylinae Brullé, 1835

\section{Genus Ellipes Scudder, 1902}

Ellipes Scudder, 1902: 309; Günther 1977: 47.

Type species. -Tridactylus minutus Scudder, 1862 (= Ellipes minuta), by original monotypy.

Ellipes deyrupi sp. nov.

http://zoobank.org/6F2B3CE8-7073-4EAE-91C9-2BB208CE113F (Figs 1-5)

Material examined.-Holotype: USA • ふै; Florida: Polk County: Sarasota Court, east of Lake Marion; 28.084972, -81.514889; 07 Aug. 2019; red type label, "Holotype Ellipes deyrupi Woo"; B. Woo leg.; CUIC. Allotype: USA • क; Florida: Polk County, same information as holotype; specimen in ethanol; CUIC. Paratypes: USA $\bullet 2 \hat{\jmath}, 2$ + , Florida: Polk County: same information as holotype; specimens in ethanol; CUIC 1 nymph; Homosassa Lane, east of Lake Marion; 28.089583,-81.519583; 07 Aug. 2019; specimen in ethanol; B. Woo leg.; CUIC $\bullet 6$,, 2 nymphs; Tiger Creek Preserve, yellow sand scrub on preserve road just east of office; 27.809, -81.483; 05 Aug. 2018; specimens in ethanol, B. Woo leg.; 2 ㅇ, FSCA; 2 , , UMMZ; 2 ㅇ, 2 nymphs, CUIC $\bullet 1$, 1 nymph ; same locality as previous; 03 Aug. 2018; dry pinned specimens; B. Woo leg.; CUIC $\bullet 1$ त; same locality as previous; 27.82158, -81.47717; 07 Jul. 2009; yellow bowl trap, scrub habitat; M. Deyrup, H. Otte, A. May leg.; ABS • 2 ภ, 2 + ; same locality as previous; 27.82158, -81.47717 ; 08 Jul. 2009; flight trap with pan, scrub habitat; M. Deyrup, H. Otte, A. May leg.; ABS $\bullet 2$, 2 क; same locality as previous; $27.82158,-81.47717 ; 10$ Jul. 2009; yellow bowl trap, Florida scrub; M. Deyrup, H. Otte, A. May leg.; ABS • 1 क; same locality as previous; 27.83383, -81.46682; 09 Jul. 2009; yellow bowl trap, scrub habitat; M. Deyrup, H. Otte, A. May leg.; ABS • 1 సं; same locality as previous; 27.83383, -81.46682; 10 Jul. 2009; flight trap with pan, scrub habitat; M. Deyrup, H. Otte, A. May leg.; ABS • 1 क; same locality as previous; 27.83383, -81.46682; 13 Jul. 2009; flight trap with pan, scrub habitat; M. Deyrup, H. Otte, A. May leg.; ABS • 2 ; same locality as previous; 27.82795 , -81.46720; 10 Jul. 2009; Townes trap with pan, scrub habitat; $M$.

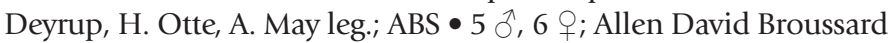
Catfish Creek State Park; 27.98503, -81.49542; 05 Jun. 2009; yellow

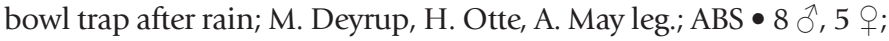
same locality as previous; 27.98598, -81.49663; 05 Jun. 2009;; flight trap with pan, scrub habitat; M. Deyrup, H. Otte, A. May leg.; ABS - 3 गे, 3 O ; same locality as previous; 27.98542, -81.49517; 05 Jun. 2009; flight trap with pan, scrub habitat; M. Deyrup, H. Otte, A. May leg.; ABS • 1 ภ, 3 क ; same locality as previous; 27.98457, -81.49606; 05 Jun. 2009; Townes trap, scrub habitat; M. Deyrup, A. May, H. Otte leg.; ABS $\bullet 2 \hat{\jmath}, 10$; same locality as previous; 27.98503, -81.49542; 05 Jun. 2009; specimens in ethanol; M. Deyrup leg.; ABS - 2 $\AA, 5$; ; same locality as previous; 27.98531, -81.49645; 06 May 2009; specimens in ethanol; M. Deyrup leg.; ABS.

Diagnosis. - Differs from all other known species of Ellipes, except E. eisneri in its flightless condition, pale white and brown coloration, lack of swimming plates, and occurrence in xeric habitat. Easily distinguished from E. eisneri by its larger size, distinctive coloration, and disjunct range.
Description._Male (holotype). (Fig. 3). Coloration in life (Fig. 2): Background color pale white; head white with interrupted blackish brown band basally and an irregular line of the same color between eyes; antennae cream, with terminal segments tinged with brown; pronotum entirely white with cream tinge on dorsum; forelegs white, with tibial spines and tarsus tinged with pale brown; middle legs white with dark markings (Fig. 3A, B); hind femora white, with small basal brown tinge, a median transverse brown band, a brown dorsal subapical chevron, apical crescents of hind femora pale salmon, hind tibiae and tarsi cream; tegmina blackish brown basally, color fading to white apically, anal area white; abdomen white, with tergites 5-8 bearing rounded blackish brown median spots; basal segment of cercus black, apical segment dark cream; ventral cercus-like organ (paraproctfortsatz of Günther [1977]) cream.

Structural characters: antennae 10-segmented, front tibia with 4 teeth; swimming plates of hind tibiae absent; forewing abbreviated, hind wings absent; scraper present on the underside of the forewing (Fig. 3C).

Terminalia as in Fig. 3D: Epiproct not longer than wide; hooks of paraprocts pale brown, with long distal part that curves upwards and tapers to end.

Female. (Fig. 4). Coloration as in male, except brown band on head not interrupted medially, median spots on tergites 5-8 more elongate than rounded. Structural characters similar to male, except stridulatory apparatus absent on underside of forewing. Subgenital plate more tapered than in E. eisneri (Fig. 4C, D).

Measurements (in $\mathrm{mm}$ ). - Male holotype. length of head and body: 3.50; length of pronotum: 0.75 ; width of pronotum: 1.2 ; width of head across eyes: 0.75 ; length of hind femur: 2 ; length of hind tibia: 1.50; length of forewing: 0.4 .

Female allotype. length of head and body: 4.10; length of pronotum: 1.00; width of pronotum: 1.20; width of head across eyes: 0.70 ; length of hind femur: 2.10 ; length of hind tibia: 1.60 ; length of forewing: 0.75 .

Etymology.-This species is named in honor of Dr. Mark Deyrup, Emeritus Research Biologist in Entomology at the Archbold Biological Station, who first collected the species and recognized it as distinct, and who has contributed the bulk of what is known about scrub tridactylid biology. Dr. Deyrup encouraged the author to describe this new species and look for other species across the southeastern U.S. and has been enormously supportive and generous with his knowledge of Florida natural history.

Common name.-Deyrup and Carrel (2012) gave this species a provisional common name of "Broussard Pygmy Mole Cricket" due to its occurrence at the Allen David Broussard Catfish Creek Preserve, but given that the species is now known to occur at other localities, I propose the common name of "Deyrup's Pygmy Mole Cricket" to recognize Deyrup's contributions to the biology and conservation of Florida scrub arthropods.

Distribution. - Restricted to the north-central Lake Wales Ridge in Polk County, FL (Fig. 5).

Habitat. - All specimens were collected in bare sand patches within yellow sand scrub habitat (Fig. 1A, B, E). These habitats have grasses and forbs scattered across the sand, along with various lichens, pines, and oaks. Tumuli and raised feeding burrows were 


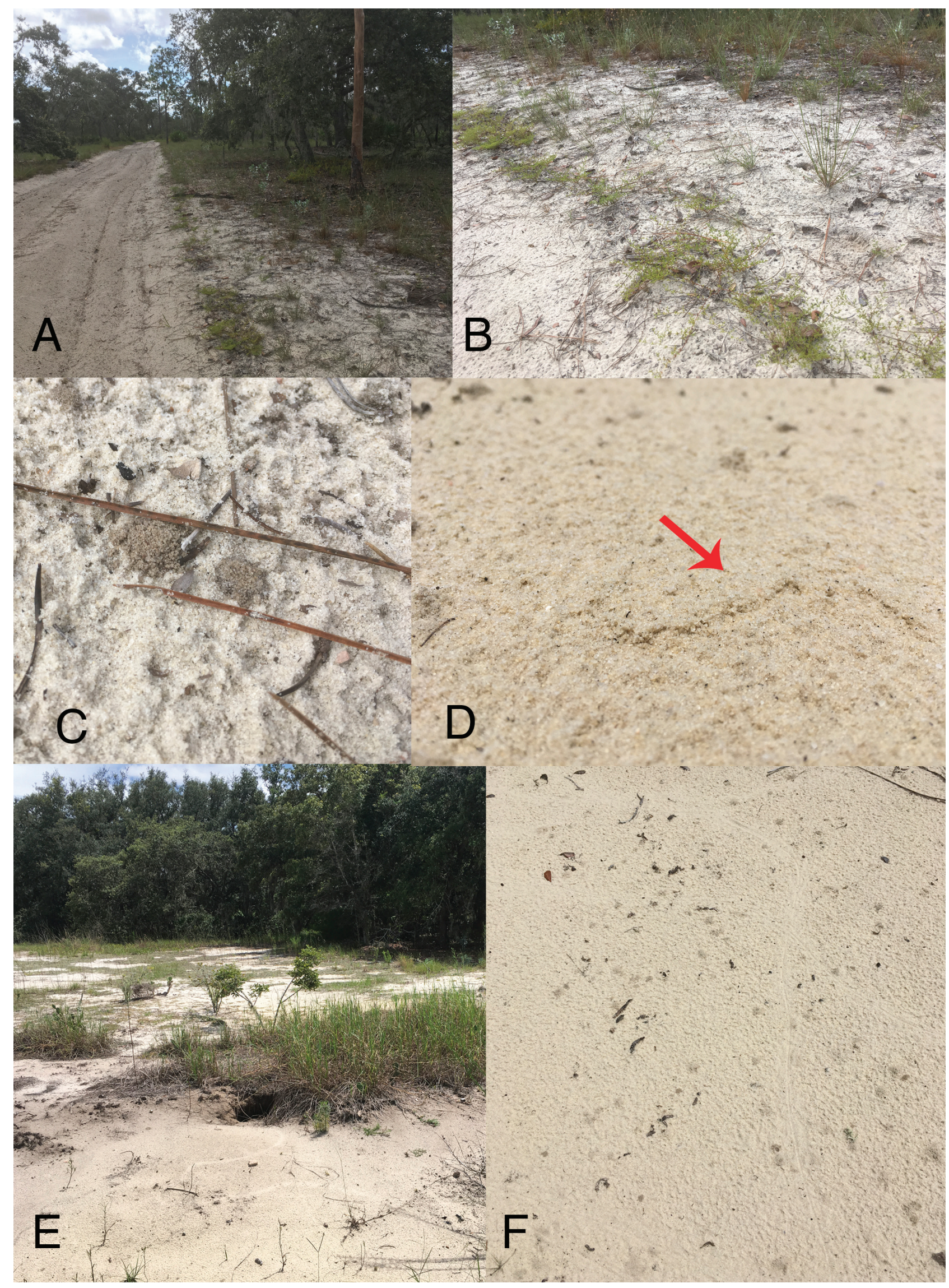

Fig. 1. Habitat and traces of Ellipes deyrupi sp. nov. A. Habitat at Tiger Creek Preserve; B. Detail of same; C. Tumuli at Tiger Creek; D. Feeding burrow at Sarasota Court; E. Habitat at same locality. Note gopher tortoise burrow entrance at center; F. Tumuli at same locality. 

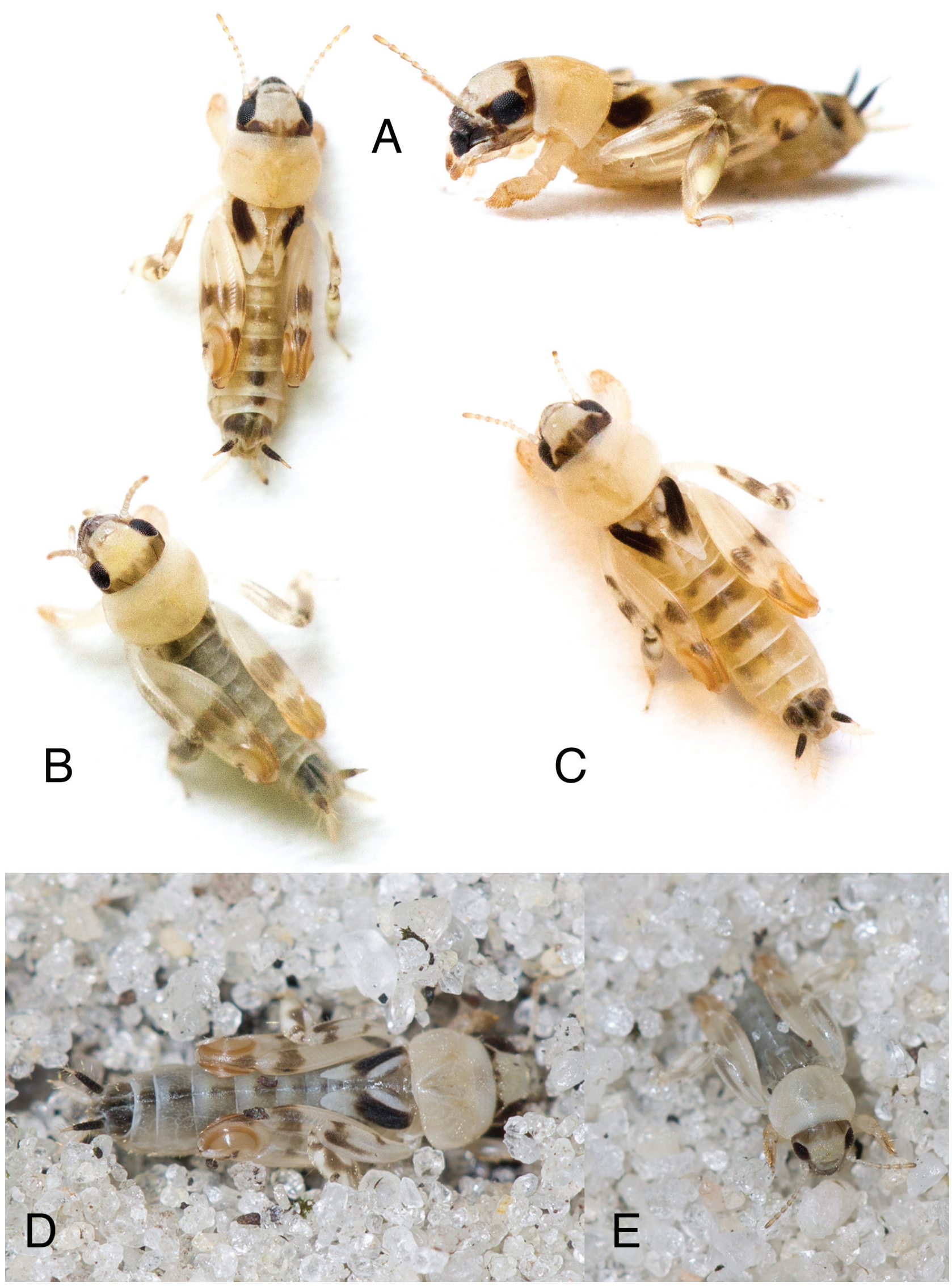

Fig. 2. Live nymph and adult images of Ellipes deyrupi sp. nov. A. Dorsal and lateral view of adult from Tiger Creek Preserve; B. Nymph from same locality; C. Adult from Sarasota Court; D. Adult burrowing in sand at Tiger Creek; E. Nymph burrowing at same locality. 


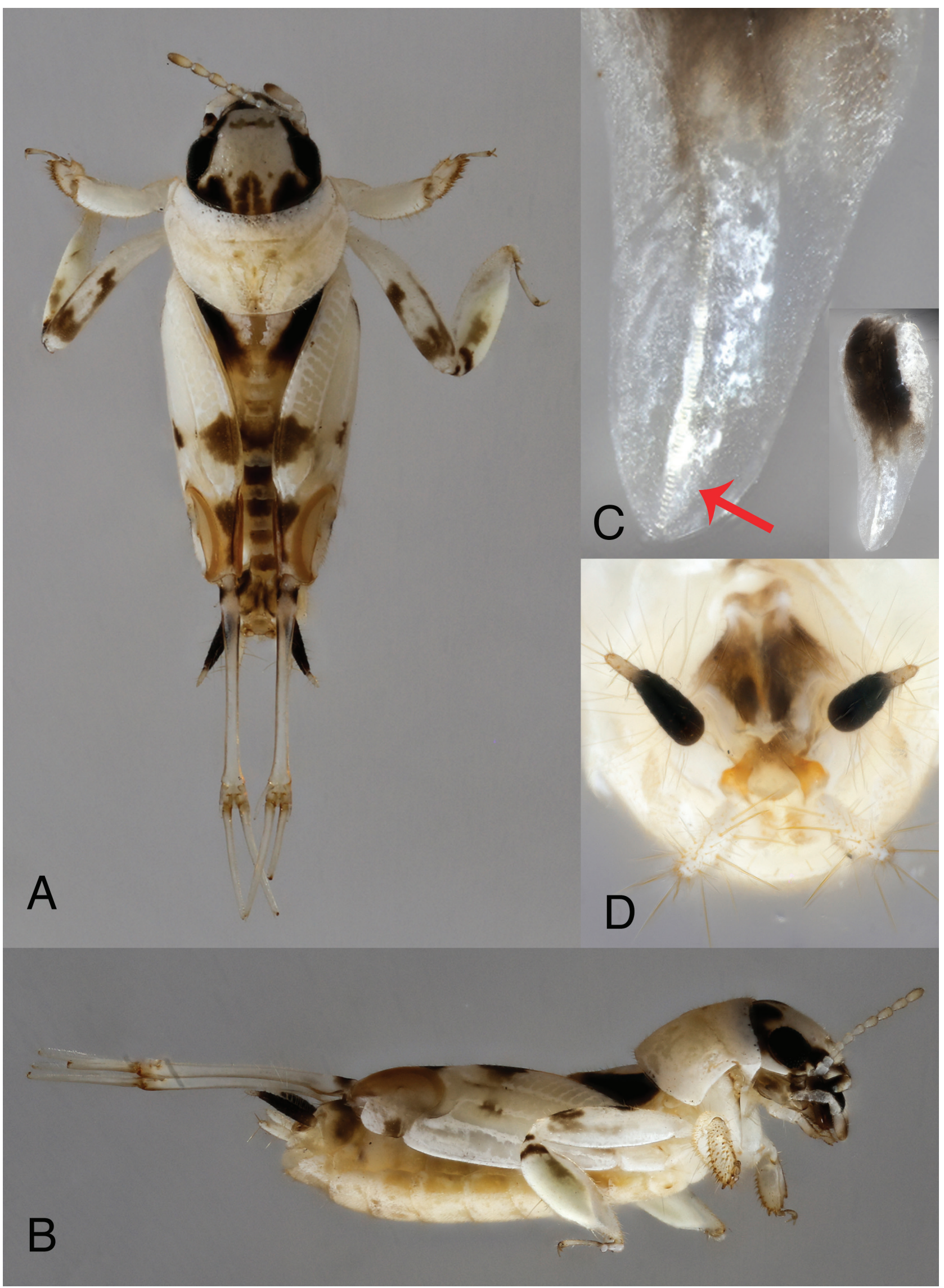

Fig. 3. Male Ellipes deyrupi sp. nov. A. Dorsal view of holotype; B. Lateral view of same; C. Underside of right tegmen showing stridulatory file. Inset shows entire tegmen; D. Terminalia. 


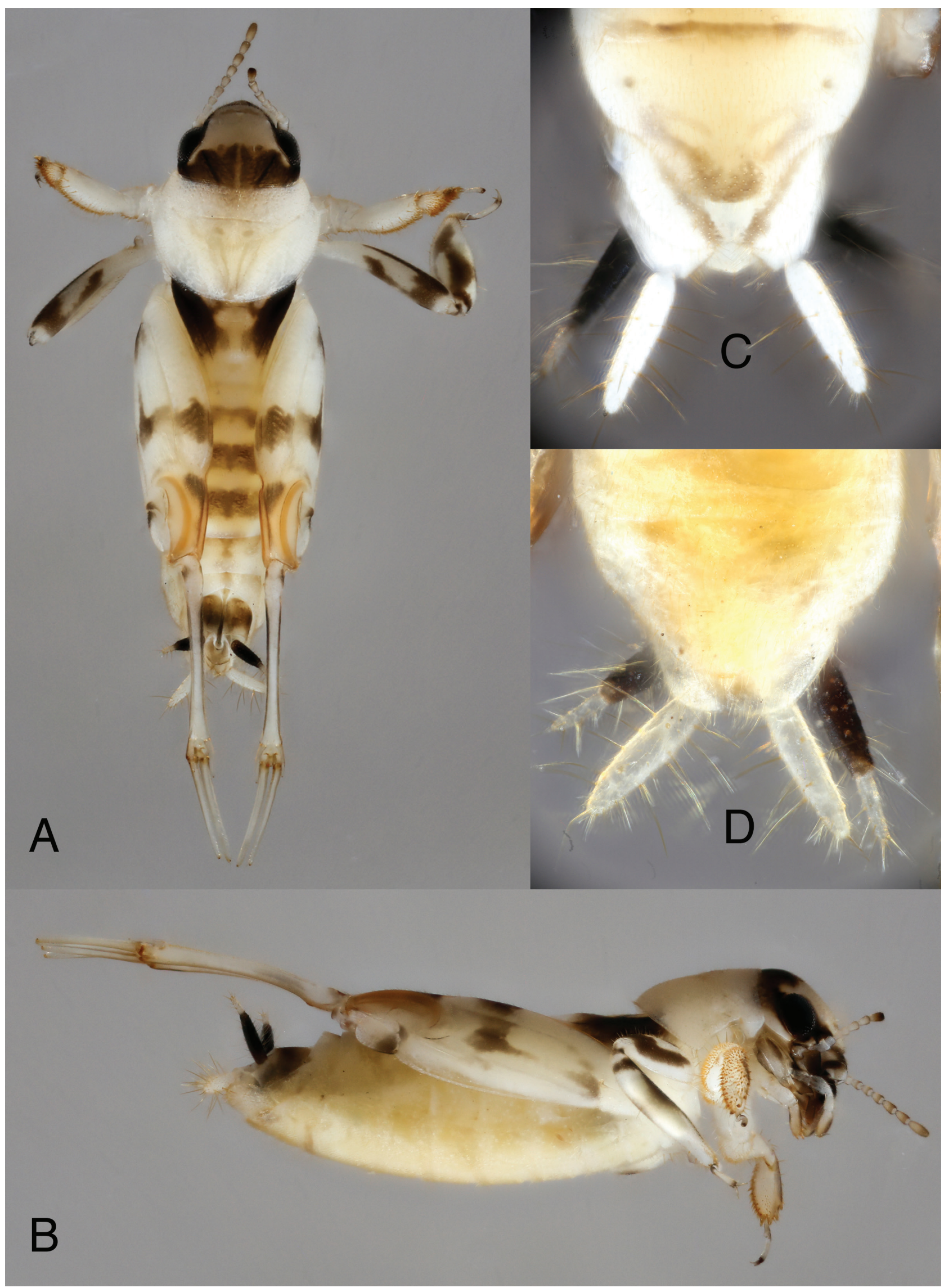

Fig. 4. Females of upland Ellipes spp. A. Dorsal view of allotype E. deyrupi sp. nov.; B. Lateral view of same; C. Subgenital plate of same; D. Subgenital plate of female Ellipes eisneri from Floral City. 
common wherever tridactylids were found (Fig. 1C, D, F). At the Tiger Creek Preserve, typical plants in the habitat included Aristida sp. grasses, Ware's hairsedge (Bulbostylis warei (Torr.) C.B.Clarke), paper nailwort (Paronychia chartacea Fernald), and sandhill skyblue lupine (Lupinus cumulicola Small). At the roadside sites east of Lake Marion, typical plants included paper nailwort (Paronychia chartacea Fernald), sandhill sky-blue lupine (Lupinus cumulicola Small), scrub Stylisma (Stylisma abdita Myint), prickly pear cactus (Opuntia sp.), and Panicum sp. grasses along the road's edge. Lichens present in this habitat included Cladonia leporina Fr., C. evansii Abbayes, and C. subtenuis (Abbayes) Mattick.

Photographs of nymphs and adults of E. deyrupi are posted by the author to BugGuide.net for public viewing, at https://bugguide.net/node/view/1575492/bgimage

\section{Ellipes eisneri Deyrup, 2005}

Figs 6-8

Ellipes eisneri Deyrup, 2005: 142.

Type material.-Holotype: USA • ठ̊; Florida: Citrus County: near Inverness, Withlacoochee Forest, Citrus Area, Forest Road 13, 1.3 mi. south State Road 44; 03 Apr. 1995; sandhill habitat with bare sand, dug from vertical burrow; M. Deyrup leg.; FSCA [not examined]. Paratypes: USA $\bullet 4 \hat{\sigma}, 4$; same information as holotype; dry pinned specimens; $1 \hat{\jmath}, 1$, FSCA; $1 \hat{\jmath}, 1$, ANSP $\bullet$ 2 Oे, 10 O; "Pine Oak Estates", State Road 488, 3.7 mi. south of junction with U.S. 41; 04 Ap. 1996; sandhill area with bare sand; specimens in ethanol; M. Deyrup leg.; ABS [examined].

Material examined.-USA, Florida $\bullet 2$; Citrus County: Floral City, side of road on Bedford Dr.; 28.746, -82.299; 28 Jul. 2018; specimens in ethanol; B. Woo leg.; CUIC $\bullet 1$ + ;Citrus County, Lecanto, side of road on 490; 28.832, -82.519; 28 Jul. 2018; photograph; B. Woo leg.; CUIC $\bullet 1$, 5 nymphs, Marion County, Dunnellon, side of road on SW Rainbow Lakes Blvd; 29.140, -82.493; 29 Jul. 2018; specimens in ethanol; B. Woo leg.; CUIC $\bullet 4$, 4 nymphs;; Marion County, Dunnellon, round dune off Indian Hill Dr.; 29.169, -82.531; 29 Jul. 2018; specimens in ethanol; B. Woo leg.; CUIC $\bullet 1$ nymph; Levy County, Bronson, side of road on NE $75^{\text {th }}$ St.; 29.443, -82.539; 30 Jul. 2018; specimen in ethanol; B. Woo leg.; CUIC.

Remark.-These are the only two sites from which the species has been known prior to this work. Herein, I present the following specimen data and localities. For photographs of living and preserved specimens of E. eisneri, see Figs 7 and 8.

Distribution.-Found on the Brooksville Ridge in Levy, Marion, and Citrus Counties, FL (Fig. 5). Probably also in adjacent Hernando County.

Habitat. - Specimens were collected in bare sand patches within open sandhill habitats (Fig. 6A, C, E). These areas have scattered lichens and forbs and are usually surrounded by oaks and pines. Tumuli and raised feeding burrows were observed at all sites (Fig. 6B, D). Typical plants present included longleaf pine (Pinus palustris Mill.), chapman oak (Quercus chapmanii Sarg.), turkey oak (Quercus laevis Walter), oak ridge lupine (Lupinus diffusus Nutt.), and dogfennel (Eupatorium capillifolium (Lam.) Small) along the road's edge. Lichens present in these habitats included Cladonia leporina Fr., C. evansii Abbayes, and C. subtenuis (Abbayes) Mattick.

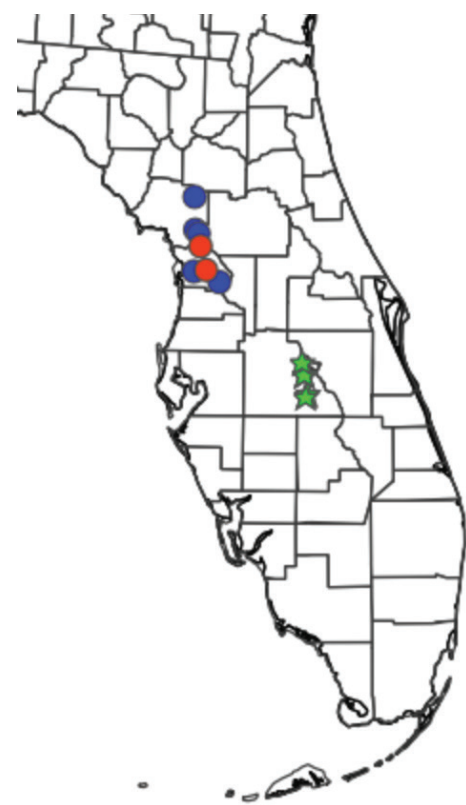

Fig. 5. Distribution of Florida upland Ellipes spp. Green stars indicate collection localities of Ellipes deyrupi sp. nov.; red dots indicate previous (2005) known collection localities for Ellipes eisneri; blue dots indicate newly reported collection localities for E. eisneri.

\section{Discussion}

Ellipes deyrupi represents the third species of Tridactylidae known to be restricted to sandy Florida uplands. Its discovery vindicates Deyrup's 1996 and 2005 statements that more species were likely to be found in such habitats and suggests that there are still more undiscovered species hiding in similar disjunct xeric habitats of the southeastern U.S. The new species can be collected using yellow bowl traps after a rain or by sifting in the sand where tumuli and feeding burrows are present. In the right conditions, it can be quite abundant, but only those knowing what to look for are likely to come across it. The genus Ellipes is now known to contain two rather distinct upland species with restricted ranges in Florida, whereas populations of scrub Neotridactylus are more ambiguous, perhaps consisting of only one wide-ranging, variable scrub species in a similar situation to the Florida endemic cockroach Arenivaga floridensis Caudell, which is also restricted to scrub and sandhill (Lamb et al. 2018). The status of scrub Neotridactylus will be explored in a forthcoming paper.

The situation of the two species of scrub Ellipes, in which there is one species (E. eisneri) on the Brooksville Ridge and another species (E. deyrupi) on the northern LWR, shares several similarities with that of Florida Geopsammodius Gordon \& Pittino, 1992 scarab beetles. These blind, flightless beetles also live just below the surface of the sand in scrub and sandhill habitats, and the author often found and collected them while searching for tridactylids (specimens are in the CUIC). Geopsammodius withlacoochee Skelley, 2006 is a Brooksville Ridge endemic like E. eisneri, and G. morrisi Skelley, 2006 is only known from the ridge habitat around Lake Marion (including the Catfish Creek Preserve), where E. deyrupi was found (Skelley 2006, Deyrup and Carrel 2012). The circumstances are somewhat different, however, as E. deyrupi also occurs at the Tiger Creek Preserve, which is inhabited by the more widespread southern LWR scarab G. relictillus (Deyrup \& Wood- 


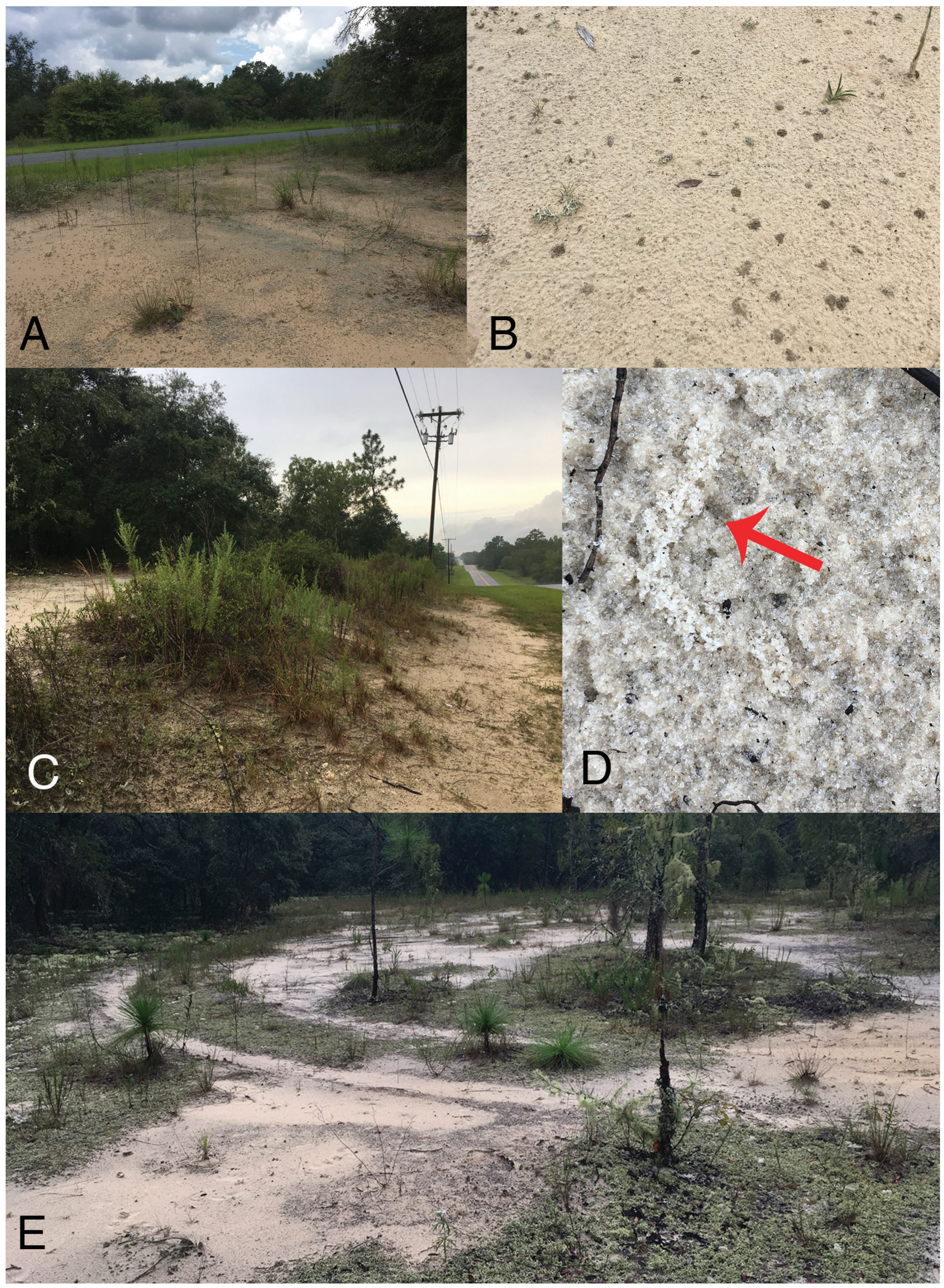

Fig. 6. Habitat and traces of Ellipes eisneri. A. Habitat at Floral City; B. Tumuli at same locality; C. Habitat at SW Rainbow Lakes Blvd; D. Feeding burrow at same locality; E. Habitat at Indian Hill Dr. 


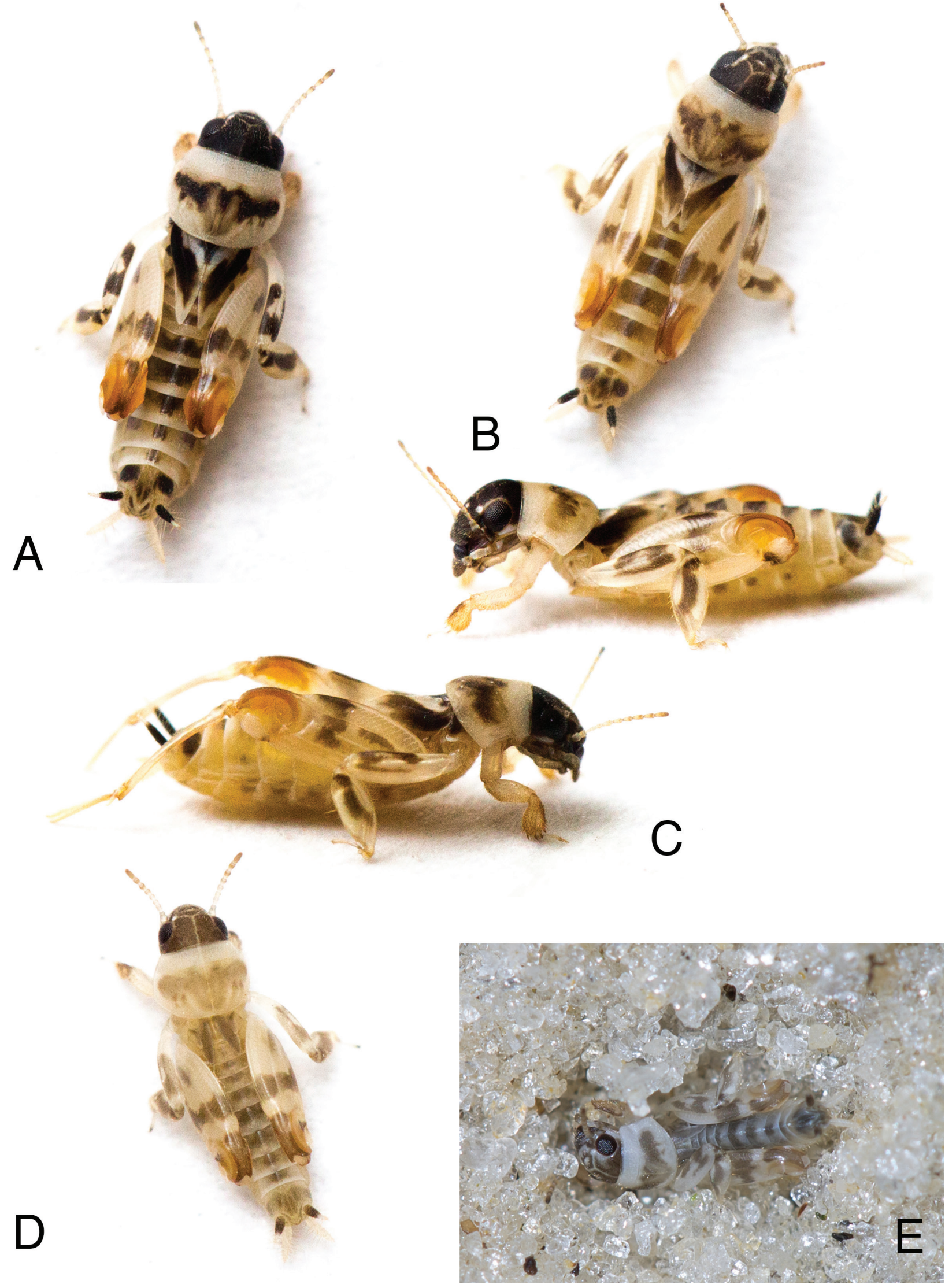

Fig. 7. Live nymph and adult images of Ellipes eisneri. A. Dorsal view of adult from Lecanto; B. Dorsal and lateral views of adult from Floral City; C. Lateral view of adult from Floral City, showing lack of tarsus; D. Nymph from Floral City; E. Nymph burrowing in sand at SW Rainbow Lakes Blvd. 


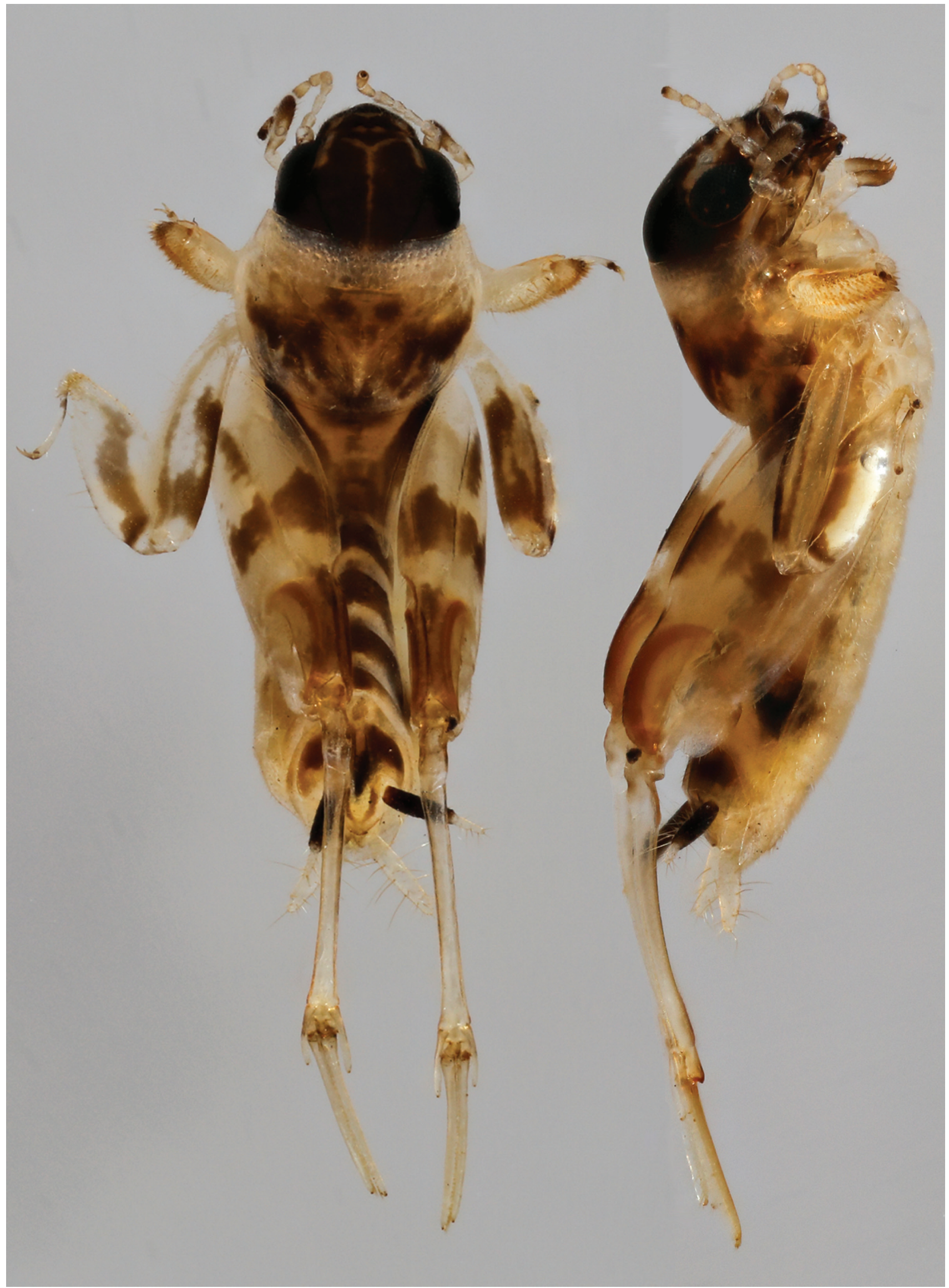

Fig. 8. Dorsal and lateral view of female Ellipes eisneri from Floral City. 
ruff, 1991). More extensive surveys of both scrub tridactylids and Geopsammodius scarab beetles may reveal more about the biogeographic patterns underlying their distributions in the state.

The ecology and behavior of scrub tridactylids is largely unknown. The only species that has been studied in any detail at all is Neotridactylus archboldi, which feeds on a layer of subsurface algae (Deyrup and Eisner 1996). Adults and nymphs of Ellipes deyrupi have been collected from May to August and in December; they likely occur year round but would be rather difficult to locate during periods of little to no rain. The males of E. deyrupi, like many other tridactylids, have a stridulatory apparatus comprised of a scraper on the underside of the tegmen and a file on the fourth abdominal tergite. Deyrup and Eisner (1996) speculated that song may be an important isolating mechanism in tridactylids, but nothing is known of the nature or function of their calls, which are likely transmitted through the sand substrate. E. deyrupi co-occurs with $N$. archboldi at all locations where it has been found, often in the same patches of sand. In other areas of Florida that have been surveyed for scrub tridactylids, only flightless Neotridactylus have been found, except on the Brooksville Ridge, where apparently only E. eisneri occurs. The fully winged Ellipes minuta sometimes occurs in scrub and sandhill (pers. obs), but this generalist species can fly and is likely present in these habitats only temporarily, when wet conditions prevail. Thus, the northern LWR appears to be the only known habitat where two scrub-restricted tridactylid species occur in sympatry. This brings up questions about interspecific competition for limited space and food resources. A vial containing live adults and nymphs of E. deyrupi and N. archboldi in sand substrate from the same locality was found to only contain $N$. archboldi after two months. This is, of course, anecdotal evidence, but it suggests that $N$. archboldi may be a better competitor in situations where space and food are limited. Geopsammodius scarab beetles, which likely feed on detritus in the sand (Skelley 2006), were often encountered in the same patches of sand, representing another potential competitor in these limited habitats.

Ellipes deyrupi may be a species of conservation concern. If the species occurred further south on the LWR, Deyrup and Carrel (2012) would most likely have detected it. The majority of its habitat on the northern LWR has been converted to housing or agriculture, and roadside sites where it still occurs are at risk of being developed. A thorough Google Maps search of this part of Polk County turned up no obvious unsurveyed areas that might contain E. deyrupi. In addition, the author could find no suitable E. deyrupi habitat while driving around in the intervening land between the three collection localities. At the Hickory Lake Scrub, only about $16.4 \mathrm{~km}$ south of the Tiger Creek Preserve, an hourlong search in December 2019 by the author turned up many $N$. archboldi but no E. deyrupi. At present, there are only two protected localities for the species, although fortunately these two preserves host large populations of E. deyrupi. Threats as described by Deyrup and Carrel (2012) include its restriction to open bare sand patches within Florida scrub and specifically within the unique yellow sand scrub found only on the LWR. This habitat can be quickly overgrown by vegetation without prescribed burns, but too frequent fires can convert it to sandhill habitat. Thus, yellow sand scrub management requires a careful balance to maintain its distinctive qualities and organisms.

The new records for E. eisneri reported here extend its range to the Northern Brooksville Ridge, and my suspicion is that it likely occurs across the entire ridge in suitable habitat. Its occurrence on the northern part of the ridge is interesting because the other Brooksville Ridge endemic Orthopteran, the flightless grasshopper Melanoplus withlacoocheensis Squitier et al., 1998, is restricted to the southern part of the ridge, with rigorous collecting efforts failing to locate it on the northern Brooksville ridge (Squitier et al. 1998). This was hypothesized to be due to the bisection of these two areas by the Withlacoochee River, which would serve as an effective barrier to flightless insects tied to specific habitats. Yet, E. eisneri occurs on both the Northern and Southern Brooksville Ridge, implying either that E. eisneri was historically present on the Ridge before the formation of the river or that it can navigate aquatic habitats. It might also have been possible for a population of tridactylids to be transported to the Northern Brooksville Ridge in bulk sand, perhaps due to human activity. Phylogenetic analysis of E. eisneri populations from both the northern and southern parts of the Brooksville Ridge might shed light on this situation.

Ellipes eisneri was relatively abundant wherever found, judging by the number of tumuli and burrows present at all sites, so it is most likely not a rare species within its known range. While its distribution appears to be wider than previously known, the fact remains that it has not been found on any other of Florida's sand ridges, and that most of the open sandhill habitat on the Brooksville ridge is under threat from human development. The Withlacoochee State Forest (Citrus Tract) is still the only known protected site for E. eisneri, as the new localities reported here are all roadside sandhill habitats. The Bronson site, however, is adjacent to the Watermelon Pond Wildlife and Environmental Area, owned by the Florida Fish and Wildlife Conservation Commission. It is almost certain that there are populations of E. eisneri present in the extensive sandhills of this protected area. The nearby Goethe State Forest and Goethe Wildlife Management Area are also likely to hold populations of E. eisneri. It would be prudent to sample within these localities during rainy weather to determine whether E. eisneri occurs there.

\section{Acknowledgements}

I am extremely grateful to Mark Deyrup for offering me the chance to describe this species and for encouraging and supporting my work on Florida tridactylids. I thank the staff of Archbold Biological Station for providing food and housing. Thanks are also due to Beatriz Pace-Aldana of the Nature Conservancy for granting me permission to collect specimens at the Tiger Creek Preserve and for providing helpful information about the area. Jason Dombroskie reviewed the original manuscript and has supported my studies of tridactylids for several years. Kyhl Austin assisted with the Cognisys focus-stacking system and zoom lens. Ann Dunn accompanied me on various collecting trips and shared my enthusiasm for tiny, understudied animals. Angela Soto, Seth Raynor, and Scott Ward provided plant and lichen identifications. A portion of this work was supported by a summer internship at the Archbold Biological Station to B. Woo. I thank the two reviewers for their comments on the manuscript. The Orthopterists' Society provided funding for publishing this paper.

\section{References}

Caudell AN (1918) Two new species of the blattid genus Arenivaga. Proceedings of the Entomological Society of Washington 20: 154-157. Choate PM (1984) A new species of Cicindela Linnaeus (Coleoptera: Cicindelidae) from Florida, and elevation of C. abdominalis scabrosa Schaupp to species level. Entomological News 95: 73-82. 
Deyrup M (1989) Arthropods endemic to Florida scrub. Florida Scientist 52: $254-270$

Deyrup M (1990) Arthropod footprints in the sands of time. Florida Entomologist 73: 529-538. https://doi.org/10.2307/3495269

Deyrup M (2005) A new species of flightless pygmy mole cricket from a Florida sand ridge (Orthoptera: Tridactylidae). Florida Entomologist 88: 141-145. https://doi.org/10.1653/0015-4040(2005)088[0141:AN SOFP]2.0.CO;2

Deyrup M, Carrel JE (2012) Conservation Status and Management of Lake Wales Ridge Arthropods Restricted to Scrub Habitat.

Deyrup M, Eisner T (1996) Description and natural history of a new pygmy mole cricket from relict xeric uplands of Florida (Orthoptera: Tridactylidae). Memoirs of the Entomological Society of Washington 17: 59-67.

Deyrup M, Woodruff RE (1991) A new flightless Psammodius from Florida's inland dunes (Coleoptera: Scarabaeidae). Coleopterists Bulletin 45: 75-80.

Gordon RD, Pittino R (1992) Current status of the American genera and species of Psammodiini (Coleoptera: Scarabaeidae: Aphodiinae). Coleopterists Bulletin 46: 260-273.

Günther KK (1975) Das Genus Neotridactylus Günther, 1972. (Tridactylidae, Saltatoria, Insecta). Zoosystematics and Evolution 51: 305-365. https://doi.org/10.1002/mmnz.19750510208

Günther KK (1977) Revision of the genus Ellipes Scudder, 1902 (Saltatoria Tridactylidae). German Entomological Journal 24: 47-122. https:// doi.org/10.1002/mmnd.4800240104

Lamb T, Justice TC, Brewer MS, Moler PE, Hopkins H, Bond JE (2018) A biogeographical profile of the sand cockroach Arenivaga floridensis and its bearing on origin hypotheses for Florida scrub biota. Ecology and Evolution 8: 5254-5266. https://doi.org/10.1002/ece3.3885
Menges ES (1999) Ecology and conservation of Florida scrub. In: Anderson RC, Fralish JS, Baskin JM (Eds) (2007) Savannas, barrens, and rock outcrop plant communities of North America. Cambridge University Press, 7-22. https://doi.org/10.1017/ CBO9780511574627.002

Myers RL (1985) Fire and the dynamic relationship between Florida sandhill and sand pine scrub vegetation. Bulletin of the Torrey Botanical Club 241-252. https://doi.org/10.2307/2996539

Say T (1825) Descriptions of new Hemipterous Insects collected in the Expedition to the Rocky Mountains. Journal of the Academy of Natural Sciences, Philadelphia 4: 310.

Scudder SH (1862) Materials for a monograph of the North American Orthoptera, including a catalogue of the known New England species. Boston Journal of Natural History 7(3): 425. https://doi.org/10.5962/ bhl.part.11211

Scudder SH (1902) On the United States Orthoptera which have been Referred to the Genus Tridactylus. Psyche 9: 309. https://doi. org/10.1155/1902/35962

Shorthouse DP (2010) SimpleMappr, an online tool to produce publication-quality point maps. [Retrieved from:] https://www.simplemappr. net [Accessed November 19, 2019]

Skelley PE (2006) A revision of the genus Geopsammodius Gordon and Pittino, 1992 (Scarabaeidae: Aphodiinae: Psammodiini). Insecta Mundi 20: $101-112$

Squitier JM, Deyrup M, Capinera JL (1998) A new species of Melanoplus (Orthoptera: Acrididae) from an isolated upland in peninsular Florida. Florida Entomologist 81: 451-460. https://doi. org/10.2307/3495936 